\title{
DNA Oxidative Damage is Correlated with JNK Activation in Hepatocytes from Rats with Experimental Insulin Resistance
}

\author{
Zagayko AL*, Kravchenko GB, Krasilnikova OA and KochubeyJu I \\ Department of Biochemistry, National National University of Pharmacy Kharkiv, Kharkiv 61068, Ukraine
}

*Corresponding author : Zagayko Andrey L, Department of Biochemistry, National University of Pharmacy Kharkiv, Kharkiv 61068, Ukraine, Tel: 380-706-3099; E-mail: andrey.zagayko@gmail.com

Received date: December 18, 2013; Accepted date: February 25, 2014; Published date: March 3, 2014

Copyright: $\odot 2014$ Zagayko AL, et al. This is an open-access article distributed under the terms of the Creative Commons Attribution License, which permits unrestricted use, distribution, and reproduction in any medium, provided the original author and source are credited.

\begin{abstract}
Oxidative stress was improved as the main complication for a variety of pathological conditions. The present study was aimed to investigate the effect of insulin resistance development on c-Jun- $\mathrm{N}$-terminal kinases (JNK) activity and DNA/RNA oxidative damage in rat's liver under fructose rich diet. Total JNK, phosphorylated JNK-1 and JNK-2 ([pThr183/Tyr185] c-Jun N-terminal protein kinase (pJNK1/2), and 8-hydroxy-2 '-deoxyguanosine (8-OHdG) amounts were measured in hepatocyte lysate. Glucose, insulin, free fatty acids, and triacylglicerols concentration and thiobarbituric acid reactive substances concentrations were measured in blood plasma. Catalase and superoxide dismutase activity, and thiobarbituric acid reactive substances (TBARS) were determined in liver homogenate. Fructose rich diet in rats provoked the insulin resistance that is accompanied by deep metabolic abnormalities detected in our study. These metabolic abnormalities induced by fructose overload are associated with an enhanced oxidative stress which appears to deregulate the JNK pathway. Consequently, accumulation of DNA/RNA oxidative damage stress marker - 8-OHdG- in hepatocytes positively correlates with JNK activity in the cells.
\end{abstract}

Keywords: Oxidative damage; Insulin resistance; c-Jun N-terminal kinases; DNA oxidative damage; High fructose diet

\section{Introduction}

At the present time, oxidative stress was improved as the main complication for a variety of pathological conditions. Especially dangerous component of oxidative stress generation is the formation of Reactive Oxygen Species (ROS). Their formation can cause damage to many cellular components such as lipids, DNA and proteins as a result of their oxidation $[1,2]$. The level of ROS, which far exceeds the possibilities of protecting cells, can lead to serious cell disorders (e.g. mutation, carcinogenesis, degenerative and other diseases, inflammation, aging, apoptosis etc.) [3]. Peroxidation products content and antioxidant enzymes activity used to be the accepted markers of oxidative stress in a numerous studies [4].

One of the consequences of oxidative stress is the formation of DNA lesions, which can result in genomic instability and lead to cell death [5]. Over 100 different types of oxidative DNA modifications have already been identified in the mammalian genome [6]. High levels of oxidative damage of DNA and RNA may significantly affect its function and cause detrimental effects to cells and organisms [7]. There are a lot of mechanisms to control the DNA/RNA oxidation levels in cells, suggesting that their damage is indeed a significant issue [8]. Guanine is the base that is most susceptible to oxidation, due to its low redox potential, and 8-oxoguanosine is the most widespread lesion. Therefore, this product is the most common and bestcharacterized lesion created by ROS. These characteristics and the strong relation between ROS production and 8-oxoguanosine make it derivatives the good cellular biomarkers to indicate the extent of oxidative stress $[9,10]$.
Speaking nowadays about investigation of the oxidative stress provocation, development and consequences it is impossible not to mentioned JNK-signaling pathways. During the last years great interest has been directed toward the c-Jun N-terminal kinases (JNK) group of mitogen-activated protein kinases (MAPKs) that are activated by oxidative stress, pro-inflammatory cytokines, mitogenic stimuli, hyperglycemia etc. Ten JNK isoforms were described from three genes known as: JNK1 (four isoforms), JNK2 (four isoforms) and JNK3 (two isoforms) [11-13]. JNKs play a key role in MAPK pathways provides the interconnection between increased ROS levels and development of disorders such as insulin resistance $[14,15]$. The JNK pathway is important in modulating cellular responses to stress. Increased oxidative stress was implicated in different animal models of diabetes, insulin resistance, metabolic syndrome etc. through activation of the JNK. JNK regulates the activities of many transcription factors and that the JNK pathway is required for the regulation of inflammatory responses, cell proliferation, and apoptosis [16-19].

Activation of the JNK signaling pathway can mediate many of the effects of stress on insulin resistance through inhibitory phosphorylation of insulin receptor substrate. JNK1 activity is believed to be implicated in obesity and insulin resistance [20]. Several studies have reported that JNK activity is increased in response to diabetes, and elevated JNK activity interferes with insulin action both in cell culture and in animal models [14,17]. The ingestion of a single, sucrose-enriched meal or elevation of portal vein fructose concentrations via fructose infusion in rats in vivo also increased hepatic JNK activity and phosphorylation of insulin receptor substrate-1 (IRS-1) on serine, a downstream target of JNK [21].

Both DNA oxidation and JNK activation could induce the apoptosis in different tissues. But whether the oxidative damage or signaling pathways play the leading role in this process remains unclear. 
Citation: Zagayko AL, Kravchenko GB, Krasilnikova OA, Ju KI (2014) DNA Oxidative Damage is Correlated with JNK Activation in Hepatocytes from Rats with Experimental Insulin Resistance. J Mol Genet Med S1: 023. doi:10.4172/1747-0862.S1-023

Page 2 of 5

One aspect of the multifaceted problem of oxidative stress is the study of tissue specific mechanisms of its course. There are a lot of data testifying that both JNK activity changes in different tissues and the DNA oxidative damage accompanied oxidative stress [22-25] but reports involving the investigations of both this indices in liver tissue are partial and not numerous.

So the present study was aimed to investigate the effect of insulin resistance development on JNK activity and DNA/RNA oxidative damage in rat's liver under fructose rich diet.

\section{Materials and Methods}

The experimental protocol and design were approved by the Institutional Animal Care and Use Committee at National Pharmaceutical University, and the animals were maintained in accordance with the guidelines for animal care and use of laboratory animals.

Healthy male Wistar rats (12 months old) weighting between 490-530 g were selected for the study. 40 animals were divided into two groups: the study group (IR, $n=20$ ) received fructose-rich diet (FRD, containing $18.3 \%$ protein, $60.3 \%$ fructose and $5.2 \%$ fat) while the control group received regular rat chow $(C, n=20)$ for 6 weeks [26].

Body weight (g) was recorded after 3 and 6 weeks of experiment.

On the $22^{\text {nd }}$ and on the $43^{\text {rd }}$ day of experiment (after 12 hours fasting period) animals were killed by decapitation $(n=10)$. Blood samples were collected for plasma preparation.

Liver was immediately removed from the animals and the sample for total JNK, phosphorylated JNK-1 and JNK-2 ([pThr183/Tyr185] cJun $\mathrm{N}$-terminal protein kinase (pJNK1/2), and 8-hydroxy-2 deoxyguanosine (8-OHdG) determination was quickly frozen in liquid nitrogen and stored at $-80^{\circ} \mathrm{C}$ until use. Tissue samples were prepared according to kit instructions (commercial Human/Mouse/Rat Total JNK Pan Specific DuoSet IC ELISA; [pThr $\left.{ }^{183} / T_{y r^{185}}\right]$ JNK1/2 EIA kit; $K$-ASSAY 8-OHdG ELISA), respectively.

Other samples of hepatic tissues were used to prepare tissue homogenate $(10 \% \mathrm{w} / \mathrm{v}$ ) in ice-cold buffer of $\mathrm{pH} 7.4$ (in $0.25 \mathrm{M}$ sucrose, 0.02 Mtriethanolamine hydrochloride containing 0.12 Mdithiothreitol). The homogenate was then centrifuged at $5000 \mathrm{~g}$ for $60 \mathrm{~min}$ to remove debris. The supernatant was again centrifuged at $\mathrm{X} 12,000 \mathrm{~g}$ for $40 \mathrm{~min}$ to obtain cytosolic fraction. All the procedures were carried out at $4^{\circ} \mathrm{C}$. Clear upper supernatant fluid was taken for Thio Barbituric Acid-Reactive Substance (TBARS) level, Catalase (C) and Superoxide Dismutase (SOD) activity determination. Protein assays were made by the method of Lowry [27].

\begin{tabular}{|l|l|l|l|l|l|}
\hline \multirow{2}{*}{ Tested parameters } & \multicolumn{2}{|l|}{ initial } & \multicolumn{2}{l|}{ after 3 weeks } & \multicolumn{2}{l|}{ after 6 weeks } \\
\cline { 2 - 7 } & $\mathrm{C}$ & $\mathrm{IR}$ & $\mathrm{C}$ & $\mathrm{C}$ \\
\hline body weight(g) & $510 \pm 5$ & $510 \pm 5$ & $512 \pm 6$ & $520 \pm 8$ & $552 \pm 7$ \\
\hline $\begin{array}{l}\text { glucose } \\
\text { (mmol/L) }\end{array}$ & $4.7 \pm 0.12$ & $4.8 \pm 0.11$ & $4.9 \pm 0.14$ & $6.9 \pm 0.12^{\mathrm{a}}$ & $5.1 \pm 0.09$ \\
\hline $\begin{array}{l}\text { insulin } \\
\text { (pg/ml) }\end{array}$ & $1290 \pm 34$ & $1310 \pm 43$ & $1340 \pm 29$ & $2110 \pm 32^{\mathrm{a}}$ & $1320 \pm 28$ \\
\hline TAGmmol/L & $0.84 \pm 0.06$ & $0.86 \pm 0.07$ & $0.85 \pm 0.09$ & $1.48 \pm 0.08^{\mathrm{a}}$ & $2920 \pm 41 \mathrm{a} \mathrm{b}$ \\
\hline
\end{tabular}


Citation: Zagayko AL, Kravchenko GB, Krasilnikova OA, Ju KI (2014) DNA Oxidative Damage is Correlated with JNK Activation in Hepatocytes from Rats with Experimental Insulin Resistance. J Mol Genet Med S1: 023. doi:10.4172/1747-0862.S1-023

Page 3 of 5

\begin{tabular}{|c|c|c|c|c|c|c|}
\hline FFA mmol/L & $0.40 \pm 0.05$ & $0.38 \pm 0.03$ & $0.39 \pm 0.03$ & $0.51 \pm 0.02^{\mathrm{a}}$ & $0.41 \pm 0.03$ & $0.68 \pm 0.04^{a b}$ \\
\hline TBARS mkmol/L & $2.57 \pm 0.18$ & $2.61 \pm 0.15$ & $2.49 \pm 0.22$ & $3.29 \pm 0.56^{a}$ & $2.51 \pm 0.21$ & $3.37 \pm 0.24^{a}$ \\
\hline \multicolumn{7}{|c|}{$\begin{array}{l}\text { Values represent the mean } \pm S D \text { of } 10 \text { experimental animals each group. } \\
{ }^{a} p<0.05 \text { (Compared to control). } \\
{ }^{b} p<0.05 \text { (Compared to IR } 3 \text { weeks). }\end{array}$} \\
\hline
\end{tabular}

Table 1: Effect of fructose rich diet on body weight, plasma levels of insulin, glucose, triacylglycerols, free fatty acids, and TBA active products after 3 weeks and 6 weeks of diet.

\begin{tabular}{|c|c|c|c|c|c|c|}
\hline \multirow[t]{2}{*}{ Tested parameters } & \multicolumn{2}{|l|}{ initial } & \multicolumn{2}{|l|}{ after 3 weeks } & \multicolumn{2}{|l|}{ after 6 weeks } \\
\hline & C & IR & C & IR & C & IR \\
\hline $\begin{array}{l}\text { SOD activity } \\
\mathrm{U} / \mathrm{mg} \text { protein }\end{array}$ & $28.5 \pm 1.2$ & $26.3 \pm 1.8$ & $27.9 \pm 1.5$ & $28.8 \pm 1.2$ & $30.1 \pm 1.8$ & $15.4 \pm 1.1^{\mathrm{a} b}$ \\
\hline $\begin{array}{l}\text { CAT activity } \\
\text { (U/mg protein) }\end{array}$ & $205.2 \pm 10.5$ & $210.5 \pm 9.8$ & $201.6 \pm 11.1$ & $225.4 \pm 8.5^{a}$ & $210.1 \pm 10.1$ & $101.9 \pm 9.4^{a} \mathrm{~b}$ \\
\hline $\begin{array}{l}\text { TBARS } \mathrm{nmol} \mathrm{MDA} / \mathrm{mg} \\
\text { protein }\end{array}$ & $0.72 \pm 0.11$ & $0.69 \pm 0.09$ & $0.74 \pm 0.12$ & $1.45 \pm 0.11^{a}$ & $0.71 \pm 0.08$ & $2.01 \pm 0.14^{a} b$ \\
\hline \multicolumn{7}{|c|}{$\begin{array}{l}\text { Values represent the mean } \pm S D \text { of } 10 \text { experimental animals each group. } \\
{ }^{a} p<0.05 \text { (Compared to control). }\end{array}$} \\
\hline
\end{tabular}

Table 2: Effect of fructose rich diet on superoxide dismutase and catalase activity, and peroxidation level in liver homogenate after 3 weeks and 6 weeks of diet.

Although fasting glycemia was significantly changed by 6 weeks of fructose overload, insulinemia was significantly increased in FRD compared to control rats (Table 1) indicating insulin resistance development in these animals.

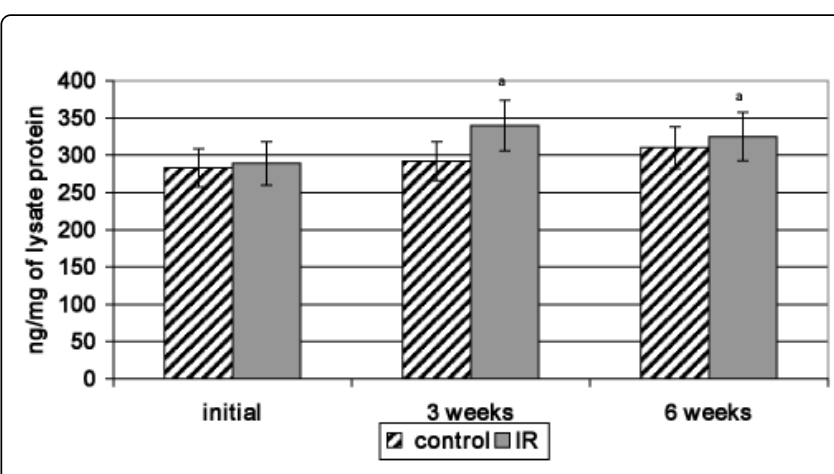

Figure 1: Level of total JNK (ng/mg of lysate protein) in hepatocyte lysate from rats' received fructose rich diet during 3 and 6 weeks.

${ }^{\mathrm{a}} \mathrm{p}<0.05$ (Compared to control).

${ }^{b} \mathrm{p}<0.05$ (Compared to IR 3 weeks).

Total JNK and pJNK1/2 levels were measured in liver tissue lysates. The observed changes after 3 and 6 weeks of experiment are displayed in Figures 1 and 2, respectively. Total JNK amount increased after 3 weeks of a diet reaching $341.3 \mathrm{ng} / \mathrm{mg}$ of lysate protein compared to control $292.7 \mathrm{ng} / \mathrm{mg}$ of lysate protein but to sixth week the total amount decreased to $325.6 \mathrm{ng} / \mathrm{mg}$ of lysate protein compared to control $312.4 \mathrm{ng} / \mathrm{mg}$ of lysate.

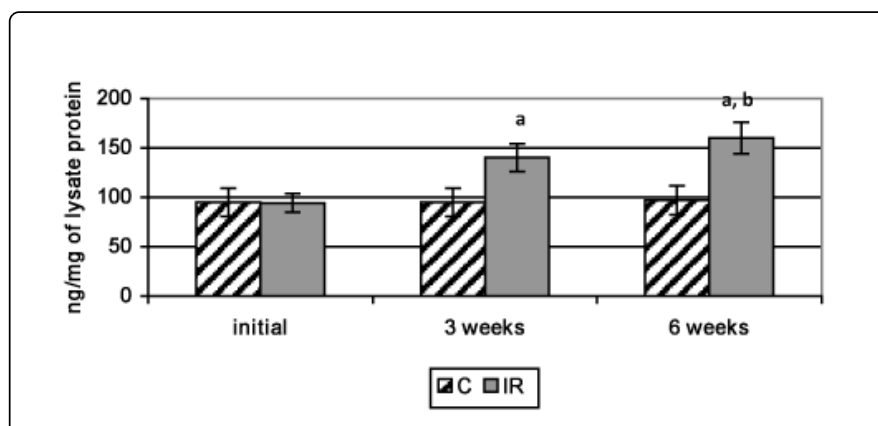

Figure 2: Level of pJNK1/2 (ng/mg of lysate protein) in hepatocyte lysate from rats' recieved fructose rich diet during 3 and 6 weeks.

${ }^{\mathrm{a}} \mathrm{p}<0.05$ (Compared to control).

${ }^{\mathrm{b}} \mathrm{p}<0.05$ (Compared to IR 3 weeks).

The different dynamics was observed as for pJNK1/2 amount. It levels in tissue lysates increased significantly to the third week of experiment ( $142.34 \mathrm{ng} / \mathrm{mg}$ of lysate protein) and continued to increase reaching to the end of sixth week $164.21 \mathrm{ng} / \mathrm{mg}$ of lysate protein.

Accumulation of 8-OHdG in hepatocytes began to be registered in early terms of experiment (Figure 3 ). And at a later period the 8OHdG formation measured in experimental groups showed the significant increasing in it content. 


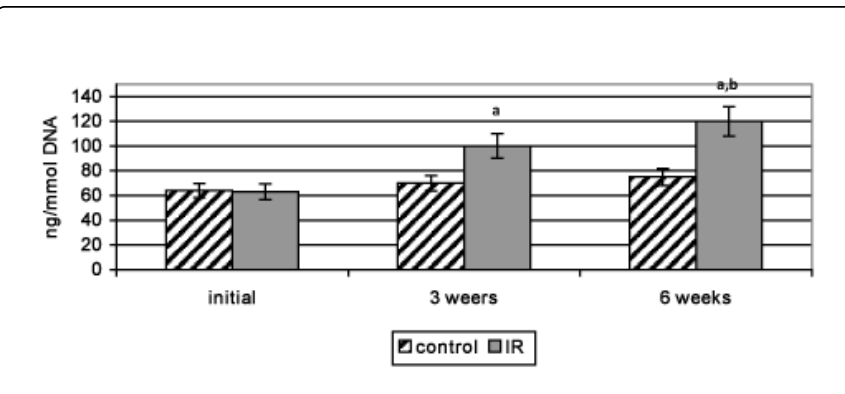

Figure 3: Level of 8-hydroxy-2 '-deaxyguanosine (ng/mmol DNA) in hepatocyte lysate from rats' recieved fructose rich diet during 3 and 6 weeks.

${ }^{\mathrm{a}} \mathrm{p}<0.05$ (Compared to control).

${ }^{b} \mathrm{p}<0.05$ (Compared to IR 3 weeks).

\section{Discussion}

In the present study, investigation of insulin resistant effects confirms our assumption about the correlation between JNK1 $\backslash 2$ activation and formation of 8-OHdGin rat liver. Feeding of rats with fructose rich diet for 3 and 6 weeks induced hyperinsulinemia, hyperglycemia, hypertriglyceridemia increasing of FFA and TBARS level in blood. Insulin levels and high triglyceridemia are known to enhance free radical production [30-32]. These results suggest that in our experiment conditions FRD led to metabolic disturbances accompanied by oxidative stress development and proatherogenic state. Also hypercaloric diet provoked the deep shift in hepatocytes metabolism that led to oxidative stress development. Oxidative stress in hepatocytes was evaluated by the measure of the validated biomarkers: catalase and SOD activities and TBARS accumulation.

But all this parameters was significantly increased only to the sixth week of experiment. A number of other studies using the FRD have also reported increased fasting plasma insulin, glucose and FFA [30] as well as a consistent hypertriglyceridemia in accordance with our results [31]. These metabolic parameters indicated the insulin resistance development [33] and could result in type 2 diabetes mellitus (DM2). Representative metabolic changes in IR rats included body weight gain, hyperglycaemia, hyperinsulinemia, increased TAG, FFA and TBARS level in blood.

In the same time, metabolic links between insulin resistance, oxidative stress and other consequences of DM2 still uncertain. The role of signaling passways disorders in this process could explain these interconnections.

Our data showed that in early terms occurred the increase of total JNK and its phosphorylated isoforms $1 / 2$ accumulation in liver. This fact pointed that the JNK overexpressed at the beginning of insulin resistance development (hyperglycemia and hyperinsulinemia). One of JNK overexpression manifestations could be the cell oxidative damage.

The DNA oxidation resulting in accumulation 8-OHdG in tissues was observed in more later early terms compared with JNA activation. These results suggest that the signaling disturbances may play the initial role in metabolic complications of hypercaloric diet and insulin resistance.
At the same time, increasing of DNA oxidation damage testifies that the oxidative stress under insulin resistance development goes far and plays the additional role of an independent factor of metabolism disturbance.

Thus, fructose rich diet in rats provoked the insulin resistance that is accompanied by deep metabolic abnormalities detected in our study. These complications induced by fructose overload are associated with an enhanced oxidative stress which appears to disregulate the JNK pathway.

Consequently, accumulation of DNA/RNA oxidative damage stress marker-8-OHdG- in hepatocytes strong positively correlates with JNK activity in the cells.

To conclude the present work gives additional insights about the potential mechanisms linking insulin resistance, oxidative stress development and their consequences.

\section{References}

1. Jones DP (2008) Radical-free biology of oxidative stress. Am J Physiol Cell Physiol 295: 849-868.

2. Kohen R, Nyska A (2002) Oxidation of Biological Systems: Oxidative Stress Phenomena, Antioxidants, Redox Reactions, and Methods for Their Quantification. Toxicol Pathol 30: 620-650.

3. Maluf SW, Marroni NP, Heuser VD, Prá D (2013) DNA damage and oxidative stress in human disease. Biomed Res Int 2013: 696104.

4. Noeman SA, Hamooda HE, Baalash AA (2011) Biochemical study of oxidative stress markers in the liver, kidney and heart of high fat diet induced obesity in rats. Diabetol Metab Syndr 3: 17.

5. Hussein J, El-Khayat Z, Taha M, Morsy S, Drees E, et al. (2012) Insulin resistance and oxidative stress in diabetic rats. Journal of Medicinal Plants Research 6: 5499-5506.

6. Pan HZ, Chang D, Feng LG, Xu FJ, Kuang HY, et al. (2007) Oxidative damage to DNA and its relationship with diabetic complications. Biomed Environ Sci 20: 160-163.

7. Nie B, Gan W, Shi F, Hu GX, Chen LG, et al. (2013) Age-dependent accumulation of 8-oxoguanine in the DNA and RNA in various rat tissues. Oxid Med Cell Longev 2013: 303181.

8. Cooke MS, Evans MD, Dizdaroglu M, Lunec J (2003) Oxidative DNA damage: mechanisms, mutation, and disease. FASEB J 17: 1195-1214.

9. Loft S, HøghDanielsen P, Mikkelsen L, Risom L, Forchhammer L, et al. (2008) Biomarkers of oxidative damage to DNA and repair. Biochem Soc Trans 36: 1071-1076.

10. Poulsen HE, Nadal LL, Broedbaek K, Nielsen PE, Weimann A (2014) Detection and interpretation of 8-oxodG and 8-oxoGua in urine, plasma and cerebrospinal fluid. Biochim Biophys Acta 1840: 801-808.

11. Bode AM, Dong $Z$ (2007) The functional contrariety of JNK. MolCarcinog 46: 591-598.

12. Bogoyevitch MA, Ngoei KR, Zhao TT, Yeap YY, Ng DC (2010) c-Jun Nterminal kinase (JNK) signaling: recent advances and challenges. Biochim Biophys Acta 1804: 463-475.

13. Oudot A, Behr-Roussel D, Compagnie S, Caisey S, Le Coz O, et al. (2009) Endothelial dysfunction in insulin-resistant rats is associated with oxidative stress and COX pathway dysregulation. Physiol Res 58: 499-509.

14. Berdichevsky A, Guarente L, Bose A (2010) Acute oxidative stress can reverse insulin resistance by inactivation of cytoplasmic JNK. J Biol Chem 285: 21581-21589.

15. Nakatani Y, Kaneto H, Kawamori D, Hatazaki M, Miyatsuka T, et al. (2004) Modulation of the JNK pathway in liver affects insulin resistance status. J Biol Chem 279: 45803-45809.

16. Amir M, Liu K, Zhao E, Czaja MJ (2012) Distinct functions of JNK and cJun in oxidant-induced hepatocyte death. J Cell Biochem 113: 3254-3265. 
Citation: Zagayko AL, Kravchenko GB, Krasilnikova OA, Ju KI (2014) DNA Oxidative Damage is Correlated with JNK Activation in Hepatocytes from Rats with Experimental Insulin Resistance. J Mol Genet Med S1: 023. doi:10.4172/1747-0862.S1-023

Page 5 of 5

17. Wei Y, Wang D, Pagliassotti MJ (2005) Fructose selectively modulates cjun $\mathrm{N}$-terminal kinase activity and insulin signaling in rat primary hepatocytes. J Nutr 135: 1642-1646.

18. Chen YR, Tan TH (2000) The c-Jun N-terminal kinase pathway and apoptotic signaling (review). Int J Oncol 16: 651-662.

19. Zhou J, Deo BK, Hosoya K, Terasaki T, Obrosova IG, et al. (2005) Increased JNK phosphorylation and oxidative stress in response to increased glucose flux through increased GLUT1 expression in rat retina endothelial cells. Invest Ophthalmol Vis Sci 46: 3403-3410.

20. Bogoyevitch MA, Kobe B (2006) Uses for JNK: the many and varied substrates of the c-Jun N-terminal kinases. Microbiol Mol Biol Rev 70: 1061-1095.

21. Vinayagamoorthi R, Zachariah B, Sridhar MG (2008) Antioxidants preserve redox balance and inhibit c-Jun-N-terminal kinase pathway while improving insulin signaling in fat-fed rats: evidence for the role of oxidative stress on IRS-1 serine phosphorylation and insulin resistance. J Endocrinol 197: 287-296.

22. Ray RM, Jin S, Bavaria MN, Johnson LR (2011) Regulation of JNK activity in the apoptotic response of intestinal epithelial cells. Am PhysiolGastrointest Liver Physiol 300: G761-770.

23. Sharma M, Gadang V, Jaeschke A (2012) Critical role for mixed-lineage kinase 3 in acetaminophen-induced hepatotoxicity. Mol Pharmacol 82: 1001-1007.

24. Nishio H, Kuwabara H, Mori H, Suzuki K (2002) Repeated fasting stress causes activation of mitogen-activated protein kinases (ERK/JNK) in rat liver. Hepatology 36: 72-80.

25. Ihara H, Sawa T, Nakabeppu Y, Akaike T (2011) Nucleotides function as endogenous chemical sensors for oxidative stress signaling. J Clin Biochem Nutr 48: 33-39.
26. Altas M, Var A, Kse C, Ozbilgin K, Ari Z (2010) Endothelial dysfunction in high fructose containing diet fed rats: Increased nitric oxide and decreased endothelin-1 levels in liver tissue. Dicle University Medical School 37: 193-198.

27. Lowry OH, Rosebrough NJ, Farr AL, Randall RJ (1951) Protein measurement with the Folin phenol reagent. J Biol Chem 193: 265-275.

28. Genet S, Kale RK, Baquer NZ (2002) Alterations in antioxidant enzymes and oxidative damage in experimental diabetic rat tissues: effect of vanadate and fenugreek (Trigonellafoenumgraecum). Mol Cell Biochem 236: 7-12.

29. Aebi HE (1984) Catalase in vitro. Methods of Enzymol. 105: 121-122.

30. Kelley GL, Allan G, Azhar S (2004) High dietary fructose induces a hepatic stress response resulting in cholesterol and lipid dysregulation. Endocrinol 145: 548-555.

31. Zaman MQ, Leray V, Le Bloc'h J, Thorin C, Ouguerram K, et al. (2011) Lipid profile and insulin sensitivity in rats fed with high-fat or highfructose diets. Br J Nutr 106 Suppl 1: S206-210.

32. Wei Y, Wang D, Moran G, Estrada A, Pagliassotti MJ (2013) Fructoseinduced stress signaling in the liver involves methylglyoxal. Nutr Metab (Lond) 10: 32 .

33. Oudot A, Behr-Roussel D, Compagnie S, Caisey S, Le Coz O, et al. (2009) Endothelial dysfunction in insulin-resistant rats is associated with oxidative stress and COX pathway dysregulation. Physiol Res 58: 499-509.
This article was originally published in a special issue, entitled: "Molecular and Cellular Aspects in Obesity and Diabetes", Edited by Dr. Masayoshi Yamaguchi, Emory University School of Medicine, USA 